\title{
ESTUDO PALEOMAGNÉTICO DA SUÍTE PALEOPROTEROZÓICA COLÍDER E MÁFICAS ASSOCIADAS, SUDOESTE DO CRÁTON AMAZÔNICO
}

\author{
Franklin Bispo dos Santos \\ Orientador: Dr. Manoel Souza D'Agrella Filho (IAG-USP) \\ 125 p. - Dissertação (Mestrado) - Defesa 18.04.2007
}

\begin{abstract}
RESUMO. Este trabalho apresenta um estudo paleomagnético realizado em rochas ácidas da Suíte Colíder e rochas máficas associadas, situadas no Norte do Mato Grosso, parte sudoeste do Cráton Amazônico. Foram coletados 5 cilindros e 42 blocos orientados de rochas ácidas e intermediárias (12 sítios) da Suíte Colíder e 75 cilindros e 3 blocos orientados de rochas máficas (11 sítios) pertencentes à Intrusiva Guadalupe e à Suíte Intrusiva Flor da Serra localizados nas proximidades de Alta Floresta, Colider, Terra Nova e Matupá. A Suíte Colíder foi datada pelo método UPb em zircões e apresenta idades entre 1,80 e 1,78 Ga. Para a Intrusiva Guadalupe ainda não existem determinações radiométricas que estabeleçam a sua idade. A investigação da mineralogia magnética feita através de curvas termomagnéticas, de indução magnética e de histerese, além do tratamento térmico e por campos magnéticos alternados, indica a hematita como sendo o principal portador magnético da maioria das rochas ácidas. Por outro lado, as rochas máficas apresentam grãos de titanomagnetita pobre em Ti, a maioria com estrutura de pseudo-domínio simples (PSD). Espécimes destas rochas após as desmagnetizações térmicas e por campos magnéticos alternados apresentaram duas direções de magnetização característica. Uma delas (componente B) é representada por direções norte (sul) com inclinações negativas (positivas) ( $\mathrm{Dm}=187.4^{\circ}, \mathrm{Im}=50.9^{\circ}, \mathrm{N}=16, \alpha_{95}=$ $11.3^{\circ}, \mathrm{K}=11.7$ ) que foram isoladas para a maioria das rochas da Suíte Colíder e máficas associadas. A outra (componente A) é representada por direções norte com inclinações positivas ( $\mathrm{Dm}=356.5^{\circ}, \mathrm{Im}=47.6^{\circ}, \mathrm{N}=3, \alpha_{95}=15.8^{\circ}, \mathrm{K}=61.9$ ) e foi encontrada para 0 gabro Guadalupe e outros dois diques máficos. Dois pólos paleomagnéticos foram determinados para estas componentes, os quais estão localizados em $289.4^{\circ} \mathrm{E}$, $-65.4^{\circ} \mathrm{N}\left(\alpha_{95}=12.9^{\circ}\right)$ (pólo SC, Suíte Colíder) e 298.8 E, 50.4 $\mathrm{N}\left(\alpha_{95}=15.1^{\circ}\right)$ (pólo IG, Intrusiva Guadalupe). 0 pólo SC (fator de confiabilidade $Q=5)$ de idade $1789 \pm 7$ Ma é considerado um pólo de referência para o Cráton Amazônico. Reconstruções paleogeográficas obtidas através de pólos de referência do Paleoproterozóico sugerem que a Laurentia, a Báltica, o Norte da China e o Cráton Amazônico formavam uma grande massa continental (Supercontinente Columbia) entre 1830-1770 Ma. Esta hipótese é reforçada por dados geológicos que evidenciam a existência de cinturões paleoproterozóicos bem alinhados nestas quatro massas continentais, sendo estes formados por cinturões magmáticos relacionados a subducções com a mesma polaridade.
\end{abstract}

ABSTRACT. This work presents a paleomagnetic study performed on felsic volcanic rocks of the Colider Suite ( 5 oriented cores and 42 oriented hand samples, 12 sites), Flor da Serra and Guadalupe mafic rocks ( 75 oriented cores and 3 oriented hand samples, 11 sites). These units are situated in the northern Mato Grosso State (southwestern Amazon Craton), close to the Alta Floresta, Colider, Terra Nova, and Matupá cities. The Colider Suite rocks have been dated by the U-Pb (zircon) method, and ages vary between 1.80 and $1.78 \mathrm{Ga}$. Radiometric determinations are not yet available for the Guadalupe Intrusive. Two very stable magnetization components were isolated after AF and thermal demagnetization: northern (southern) directions with moderate to steep downward (upward) inclinations (component B $-\mathrm{Dm}=187.4^{\circ}, \mathrm{Im}=50.9^{\circ}, \mathrm{N}=16, \alpha_{95}=11.3^{\circ}, \mathrm{K}=11.7$ ) were isolated for most Colider Suite rocks and associated mafic rocks. Northern upward direction with moderate inclination (component $A D m=356.5^{\circ}, \mathrm{Im}=47.6^{\circ}$, $\mathrm{N}=3, \alpha_{95}=15.8^{\circ}, \mathrm{K}=61.9$ ) was found for the Guadalupe gabbro and other two mafic dikes. Rock magnetism experiments show that the magnetization is carried by hematite, which is probably primary in origin, in the felsic rocks. In the mafic rocks the main magnetic carrier is Ti-poor titanomagnetite in the PSD magnetic structure. Two paleomagnetic poles were determined for these components, which are located at $289.4^{\circ} \mathrm{E},-65.4^{\circ} \mathrm{N}\left(\alpha_{95}=12.9^{\circ}\right)$ (SC pole, Colider Suite) and $298.8^{\circ} \mathrm{E}, 50.4^{\circ} \mathrm{N}\left(\alpha_{95}=15.1^{\circ}\right)$ (IG pole, Guadalupe Intrusive). An age of $1.780 \pm 7 \mathrm{Ma}$ is attributed to pole SC (quality factor $Q=5$ ), which is considered a key pole for the Amazon Craton. Paleogeographic reconstructions using Paleoproterozoic key poles suggest ix that Laurentia, Baltica, North China and the Amazon Craton were located in laterally contiguous positions forming a huge continental mass (Columbia Supercontinent) at 1830-1770 Ma ago. This hypothesis is reinforced by the geological evidence that paleoproterozoic mobile belts of these four continental masses fit well in the reconstruction, being formed by contemporaneous subduction-related magmatic arc belts with the same tectonic polarity. 